\title{
PHYTOTESTING OF THE SOILS OF URBAN PEDOCOMPLEXES IN RESIDENTIAL AREAS OF PERM, RUSSIA
}

\author{
EREMCHENKO, O. Z. - MitRaKova, N. V. - MoskVina, N. V.* \\ Perm State University, 15, Bukirev str., 614990 Perm, Russia \\ (phone: +73422396412) \\ *Corresponding author \\ e-mail:nvmoskvina@mail.ru \\ (Received $12^{\text {th }}$ Nov 2018; accepted $12^{\text {th }}$ Feb 2019)
}

\begin{abstract}
The response of watercress Lepidium sativum L. to the basic properties and toxicity of the soils has been established. When assessing the ecological state of the soil cover in residential areas of the city of Perm, the concept of the urban pedocomplexes as combination of soil and man-made surface formations on the same soil-forming rocks within a certain functional zone was applied. The problem of choosing a test control was solved by using vermiculite with Knop solution as a root substrate. Phytotesting showed mainly satisfactory conditions of the upper layers of the soils in urban pedocomplexes. At the same time, in the area of relatively old buildings, a trend towards the emergence of soil toxicity was revealed.
\end{abstract}

Keywords: ecological state, urban soils, watercress, toxicity, test-control

\section{Introduction}

The soil cover of urban landscapes has a complicated mosaic pattern; it consists of transformed and degraded soils and technogenic surface formations (TSFs) which are distinctly different from natural soils and often times are instantiated by lower biological activity and toxicity level. The process of the urban soil cover formations, without reference to the location, involves the following general factors: destruction of natural soils and formation of organo-mineral and mineral layers instead, accumulation of urban artifacts and rock formations in the soil profile, discontinuity of soil formation due to building activities, accumulation of heavy metals, oil products and salts (Dobrovolskiy, 1997; Marcotullio, 2011; Bardina et al., 2013; Ivanov and Kudeyarov, 2015; Yang and Zhang, 2015).

Perm is a large industrial city of the Russian Federation (its area is $780 \mathrm{~km}^{2}$, population - over 1 million people). It was founded in 1724 as a settlement at a copper smelter. Originally the current center of the city was mainly represented by wooden two- and three-storey buildings. The central part of the city was formed in the period between 1780 and 1860. There were a few stone buildings - mainly administrative buildings, churches, cathedrals, some of which have survived to the present day. In between 1930's-1970's new residential areas appeared in the place of former villages and pine forests; also selective reconstruction of the old part of the city was pursued as well. Currently, the city is located on both banks of the Kama River. The essential industrial and residential buildings are located on the left bank, as well as the public center of the city (Nechaev, 2000).

In the residential part of Perm artificial groups of plants predominate (parks, lawns, plantings in yards). The air quality of the urban environment depends on the state of the soil and vegetation. Therefore, optimization of the environment is not possible without the regulation of the soil cover functions and properties. 
The territory of the city of Perm, which is located in the valley of the Kama River, has a natural soil-lithological heterogeneity. Some specific factors were involved in urban soil formation: the widespread use of carbonate gravel in building and road works; the use of de-icing salts (sodium chloride and, to a lesser extent, potassium) on the roads, dumping lowland peat on the surface of organo-mineral and mineral grounds; relatively short duration of urban soil formation (several decades). Due to the high horizontal and vertical heterogeneity of the current soil cover, it grants a possibility for the concept of urban pedocomplexes - a combination of soil and man-made surface formations on the same soil-forming rocks within a certain functional zone (Shestakov et al., 2013). The concept of urban pedocomplexes has greatly facilitated the mapping and assessment of the soil structure of the Perm Region cities (Eremchenko et al., 2016).

Toxicity and low biological activity of urban soils could be induced by both factors unfavorable properties (compaction, alkalinity, etc.) and accumulation of pollutants (heavy metals, salts, petroleum, etc.) (Dobrovolskiy, 1997; Poyat et al., 2007; Byrne, 2008; Sizov, 2008; Pickett and Cadenasso, 2009; Lisovitskaya and Terekhova, 2010; Marcotullio, 2011; Ivanov and Kudeyarov, 2015; Yang and Zhang, 2015). Currently, biotesting methods are widely used in soil quality control. These methods are mandative in the environmental practice in the USA, France, Germany, Sweden, Japan (Keddy et al., 1995; Juvonen et al., 2000; Maxam et al., 2000; Rivett et al., 2011; Van der Vliet et al., 2012; Romero-Freire et al., 2015). Method of soil biotesting evaluates the reactions of animals, microorganisms and plants. However, the priority is often given to higher plants that creates photosynthesizing cover, which is the basis of trophic interactions in biocenosis. The sensitivity of plants to soil and chemical effects is reflected in growth, morphological and biochemical parameters. Phytotesting is the basis of a method for assessing soil toxicity and their resistance to pollution (Gong et al., 2001; Voronina, 2009; Mayachkina and Chugunova, 2009; Kolesnikov et al., 2010; Lisovitskaya and Terekhova, 2010; Timofeev et al., 2010; Terekhova, 2011; Bardina et al., 2013, 2014; Nikolaeva and Terekhova, 2017; Gareeva, 2018). Many authors showed the effectiveness of the use of cultivated plants' small seeds, in particular of the watercress Lepidium sativum L. This species showed its sensitivity in response to pollutant analysis, both by individual pollutants (heavy metals, hydrocarbons, radioactive substances), and their integrated effect (Shunelko and Fedorova, 2000; Czerniawska-Kusza et al., 2006; Sujetovienè and Griauslyte, 2008; Lisovitskaya and Terekhova, 2010).

The goal of our research is to assess the ecological state of the surface soil layers in urban pedocomplexes of residential areas of Perm using the phytotesting method.

\section{Materials and Methods}

\section{Laboratory experiment design}

At the first stage of our research, we worked on a problem of examining the response characteristics of Lepidium sativum L. as a testing culture to the basic properties of regional soils and their contamination with some heavy metals. We used upper horizons of Chernozems, Retisols (Humic) and Albic Retisols. Soils were contaminated with lead nitrate at the rate of $1000 \mathrm{mg} \mathrm{Pb}$ per $1 \mathrm{~kg}$ of soil, cadmium sulfate at the rate of $500 \mathrm{mg} \mathrm{Cd}$ per $1 \mathrm{~kg}$ of soil. Lead was introduced in an amount corresponding to the high level of pollution noted in the urban soils (Eremchenko and Moskvina, 2005). The 
toxicity of $\mathrm{Cd}$ is several times higher than that of other heavy metals (Kabata-Pendias, 2011), so its dose was halved relating to $\mathrm{Pb}$.

The study of the soil cover was carried out in the residential zone of the multistorey building on the left-bank part of the city, which occupies about $60 \mathrm{~km}^{2}$. As an object of study, we took the surface soil layers within the urban pedocomplexes (UPC) on eluvial-deluvial loams with outcrops of indigenous carbonate rocks (UPC-1), on ancient alluvial sands (UPC-2), on low-power deluvium, underlain by sand and sandy sediments (UPC-3), on alluvial sediments (UPC-4). From 15 to 28 soil samples from a depth of 0-15 cm were taken within each UPC (Fig. 1).
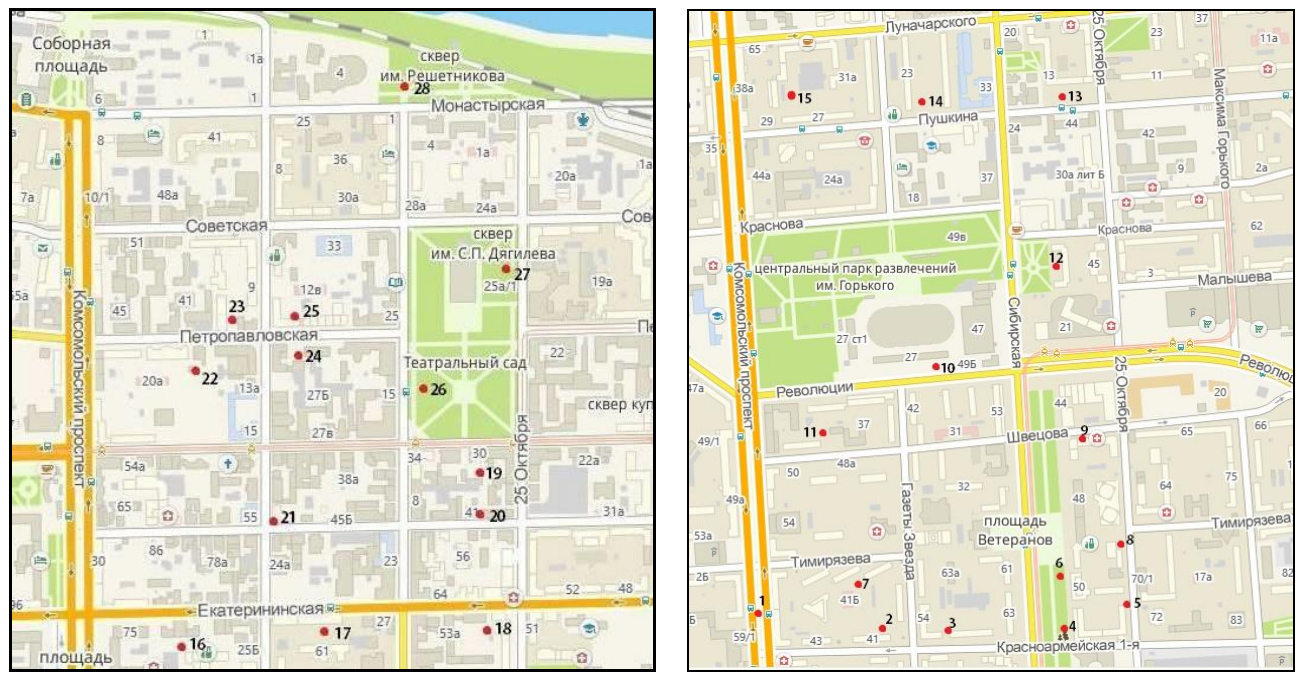

Figure 1. Sampling points within the UPC-1

In the samples of natural and urban soils there was determined:

- The content of organic carbon according to Tyurin.

- $\mathrm{pH}_{\mathrm{water}}, \mathrm{pH}_{\mathrm{KCl}}$-by potentiometric method.

- Hydrolytic acidity was determined by the Kappen method.

- Absorption capacity was calculated by adding the sum of the bases and hydrolytic acidity.

- Absorption capacity in carbonate samples - by the Melich method.

- Mobile phosphates and potassium - according to Kirsanov.

- The mobility of heavy metals, expressed in terms of their activity (-lg [Cd] and $-\lg [\mathrm{Pb}])$, by the ion-selective method using a $\mathrm{pH}$-meter-ionomer.

Watercress was grown on natural and urban soils within 10 days. The total weight of plants (threefold), the height and weight of one plant in 30-fold repetition were measured. Of a test control there were plants grown on vermiculite with a Knop nutrient solution $\left(1 \mathrm{~g} / \mathrm{l} \mathrm{Ca}\left(\mathrm{NO}_{3}\right)_{2}, 0.25 \mathrm{~g} / \mathrm{l} \mathrm{KH}_{2} \mathrm{PO}_{4}, 0.25 \mathrm{~g} / 1 \mathrm{MgSO}_{4}, 0.125 \mathrm{~g} / 1 \mathrm{KCl}\right.$, $0.0125 \mathrm{~g} / \mathrm{FeCl}_{3}$ ), which was watering once after the seeds had been planted.

In the biotesting of urban soils, choosing the control turns to be very difficult. There are no analogues of these formation in nature. Their toxicity and low bioactivity can be caused by both a multitude of pollutants and common adverse properties. As a test control, we suggested plants grown on vermiculite, a natural mineral from the group of hydromica. Vermiculite of small fractions (up to $1 \mathrm{~mm}$ ) is produced in the Chelyabinsk region, Russia, and is recommended for growing seedlings, germinating seeds and 
rooting plants. The method we have developed has a patent of the Russian Federation (Eremchenko and Mitrakova, 2017), is positively recommended in the practice of various soil grounds biotesting.

For statistical processing of the obtained data, regression and correlation analyses were used at a $95 \%$ probability level. Comparison of the samples was carried out by the dispersive non-parametric method (Kruskal-Wallis test). Significant differences between the compared average values were considered with a confidence level of $95 \%$ and higher $(\mathrm{P}<0.05)$. The significance of differences with the test control was evaluated statistically by Student's criterion $(\mathrm{P}<0.05)$. The figures and tables show the arithmetic mean of biological replicates and standard errors.

\section{Results}

\section{The response of the test culture on the basic properties of regional soils}

During the phytotesting experiment of regional soils, the watercress responded to the humus content, $\mathrm{pH}$, sufficiency of potassium and phosphorus available forms. The height and weight of the testing culture was closely correlated with the main indicators of soil fertility (Figs. 2-6).

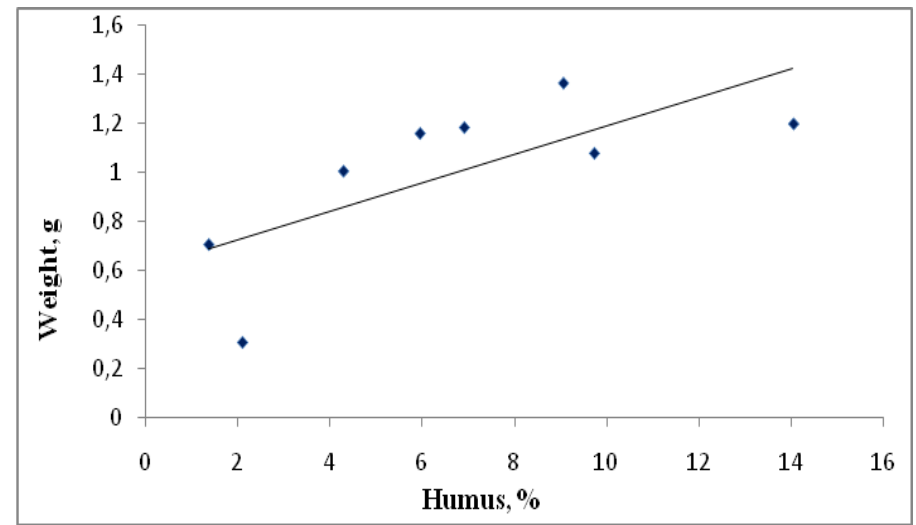

Figure 2. Dependence of the total weight of watercress $(\mathrm{g})$ on the content of humus (\%) in soils: $y=0.676+0.055 x ; R=0.64 ; F=4.92 ; P=0.021$ (here and after: $R$-correlation coefficient, $F$-Fisher's criterion, $P$ - the level of significance of the null hypothesis)

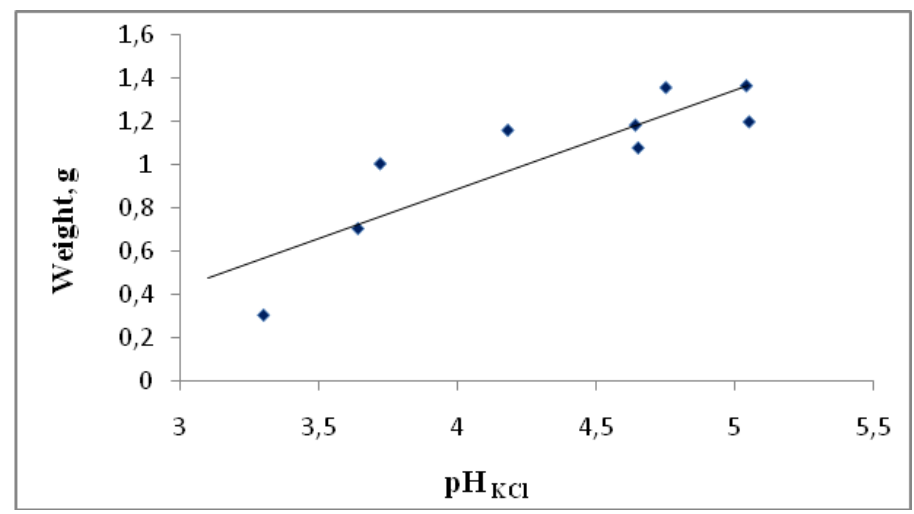

Figure 3. Dependence of the total weight of watercress $(\mathrm{g})$ on $\mathrm{pH} \mathrm{KCl}_{\mathrm{KCl}}$ of the soil: $y=-0.98+0.46 x ; R=0.84 ; F=17.4 ; P=0.002$ 


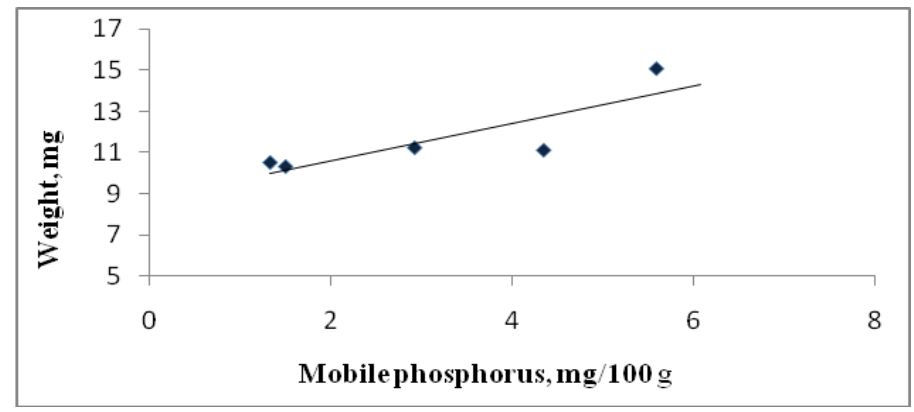

Figure 4. Dependence of the plant weight $(\mathrm{mg})$ on the content of mobile phosphorus $(\mathrm{mg} / 100 \mathrm{~g}$ soil $)$ in the dark gray soil: $y=8.8+0.9 x ; R=0.84 ; F=7.3 ; P=0.004$

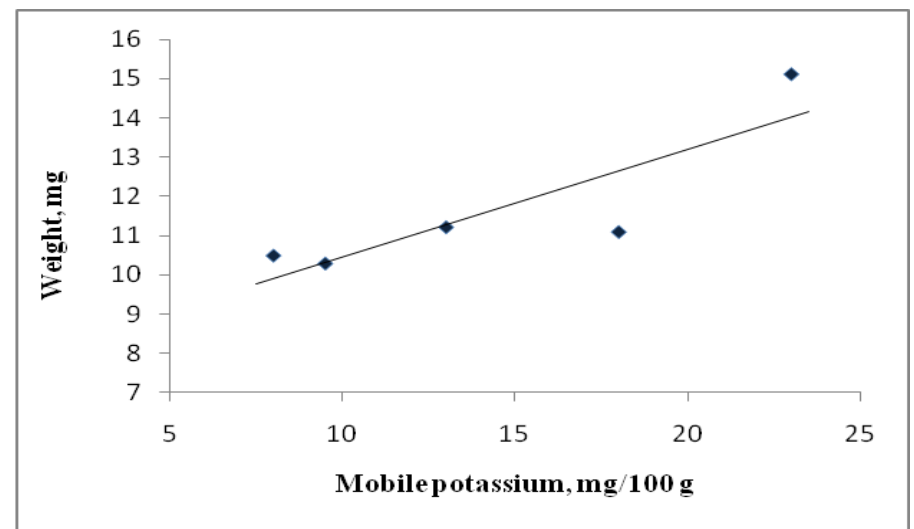

Figure 5. Dependence of the plant weight $(\mathrm{mg})$ on the content of mobile potassium $(\mathrm{mg} / 100 \mathrm{~g}$ of soil) in dark gray soil: $y=7.71+0.27 x ; R=0.86 ; F=8.9 ; P=0.0024$

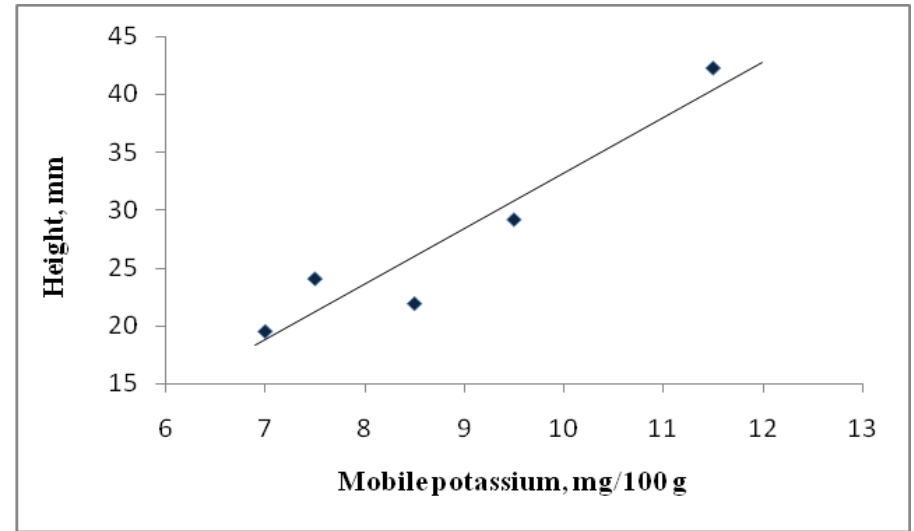

Figure 6. Dependence of the plant height $(\mathrm{mm})$ on the content of mobile potassium $(\mathrm{mg} / 100 \mathrm{~g})$ in dark gray soil: $y=-14.7+4.8 x ; R=0.95 ; F=28.0 ; P=0.0001$

In Perm Krai, which is considered to be an industrialized region with high transport load, indigenous soils accumulate $\mathrm{Pb}, \mathrm{Cd}, \mathrm{Zn}, \mathrm{Cu}, \mathrm{Cr}$ and other heavy metals (Voronchikhina and Zaporov, 1998; Eremchenko and Moskvina, 2005; Vasilyev and Chashchin, 2011). 
In our experiments on the pollution of natural soils, it was established that the height and weight of the watercress depended on the contamination by cadmium and lead. Some dependencies between height, mass of the testing culture and the mobility of metals in dark gray soils are presented in the Figures 7-10.

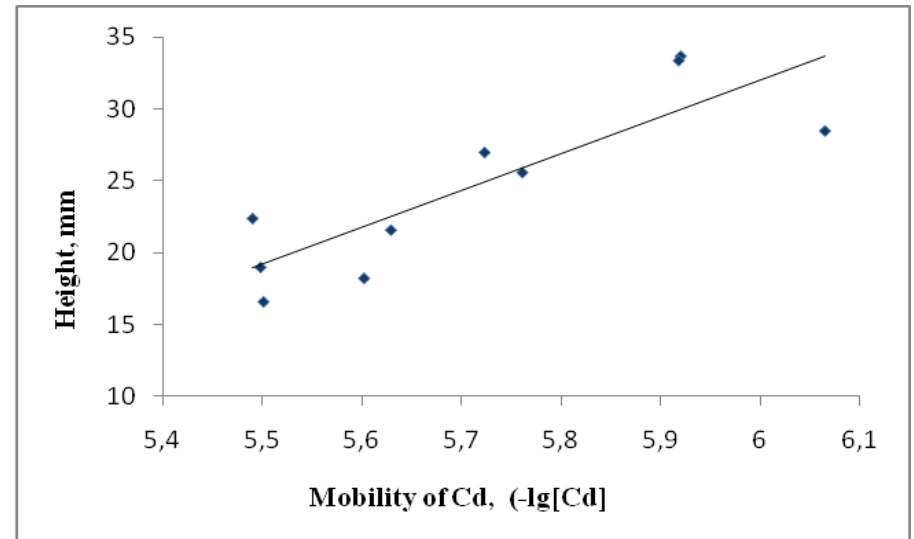

Figure 7. Dependence of the plant height on cadmium mobility (-lg $[C d])$, in dark gray soils: $y=-116.8+24.8 x ; R=0.84, F=19.8 ; P=0.005$

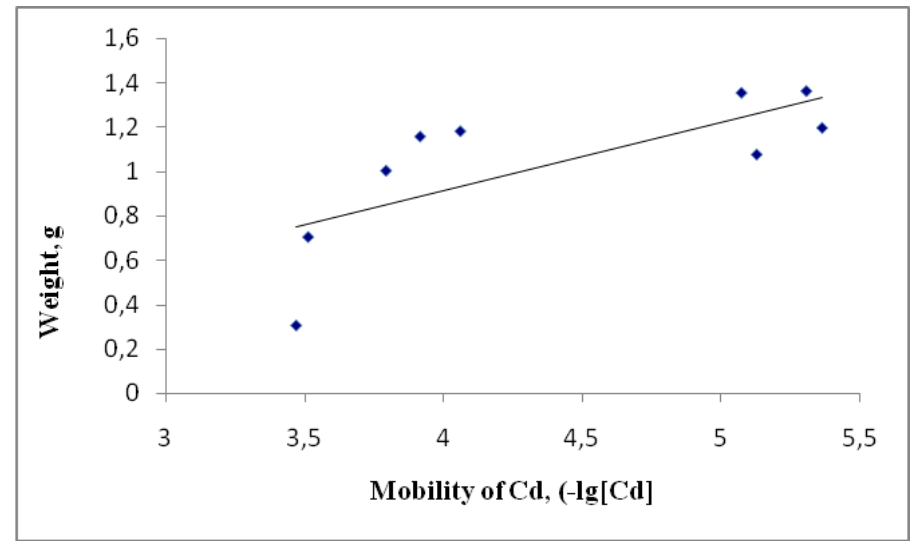

Figure 8. Dependence of the total weight of watercress $(\mathrm{g})$ on the mobility of cadmium $(-\lg [C d])$ in soils: $y=-2.297+0.638 x ; R=0.98 ; F=104.8 ; P=0.003$

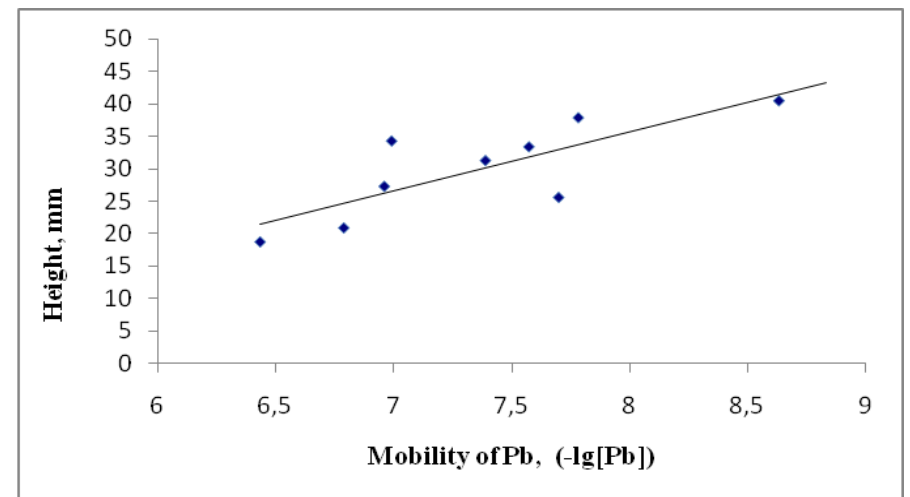

Figure 9. Dependence of the plant height $(\mathrm{mm})$ on the mobility of lead $(-\lg [\mathrm{Pb}])$ in dark gray soils: $y=-36.7+9.064 x ; R=0.80, F=12.1 ; P=0.0002$ 


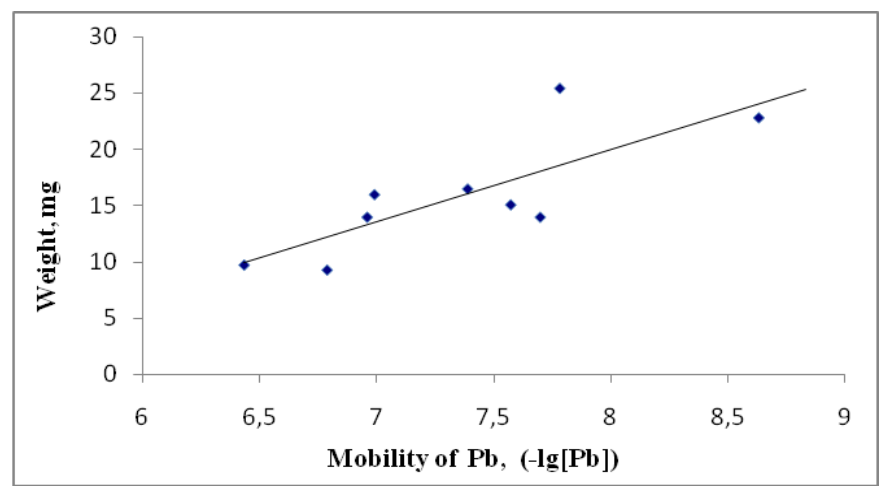

Figure 10. Dependence of the plant weight $(\mathrm{mg})$ on the mobility of lead $(-\lg [\mathrm{Pb}])$ in dark gray soils: $y=-31.61+6.4 x ; R=0.80, F=11.9 ; P=0.003$

In the biotesting of urban soils, we considered plants grown on vermiculite with Knop's solution as a test-control. We compared height and weight of plants with watercress grown on the natural soils of our region.

Chernozems are the most fertile soil, so the height of plants that grew on chernozem was lowered by $30 \%$ compared to the test control, on dark gray soil (Retisols (Humic)) by $50-60 \%$, sod-podzolic soil (Albic Retisols) - 60-70\%. The decrease in the mass of the plant was $33 \%$ on black soil, and $60-70 \%$ on gray soils and sod-podzolic soil relative to the test control. Thus, the properties of black soil were the most favorable for the plants, however, the height and weight of the plants were still lower than that of vermiculite. Apparently, the nutrients from the Knop solution turned out to be more accessible.

Based on the results of the experiment, we proposed the state of anthropogenic (manmade) soil or ground to be satisfactory with a decrease in the development of watercress relative to the test control by $10-30 \%$; unsatisfactory - with a decrease of $30-50 \%$; and at a reduction rate of more than $50 \%$, it is environmentally hazardous (Eremchenko and Mitrakova, 2017).

\section{Soil properties of residential areas of Perm}

Urban soil is synlythogenic soil, as soil formation proceeds simultaneously with the accumulation of mineral and organic material on the surface; as a result, a profile of different thickness and degree of layering is being formed. The main diagnostic horizon of urban soils is the urbic horizon. In WRB (2006), the urbic horizon was defined as a qualifier for Technosols by the presence of a layer containing $20 \%$ of artifacts, including $35 \%$ of construction waste. In the Russian Federation, urban soils with a horizon urbic are classified as urbostratozem types (Prokof'eva et al., 2014).

Urbostratozems were prevailed in the UPC of residential areas of the city of Perm (Fig. 11). They are mainly formed during the cultivation by dumping (and repeated) lowland peat to the surface. Some properties of urbic are given in Table 1. Urbostratozems are not rich in humus, they have a slightly alkaline $\mathrm{pH}$ and an average cation exchange capacity.

In domesticated (peat-eutrophied) urbostratozems (Fig. 12), on the average, the amount of humus is 2 times higher, the $\mathrm{pH}$ is close to neutral, and the absorptive capacity is markedly increased. In the urbostratozem, as a rule, there was a small amount of carbonates. 


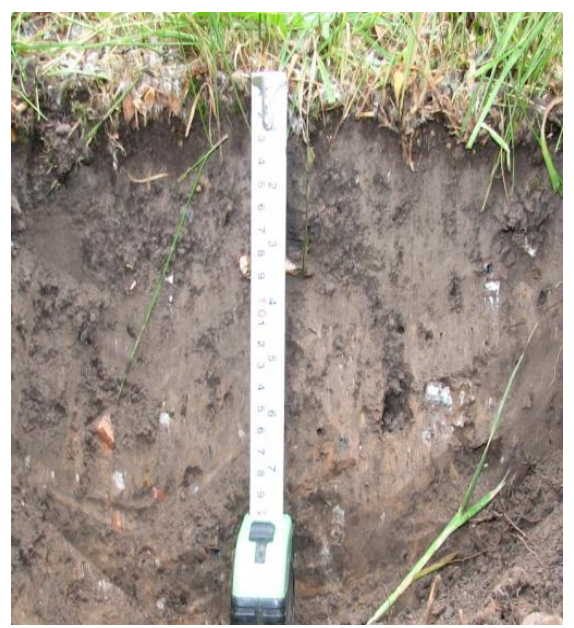

Figure 11. Urbostratozem

Table 1. Properties of urbic horizon $(0-15 \mathrm{~cm})$ in urbostatozems of residential areas of Perm

\begin{tabular}{|c|c|c|c|c|c|c|c|c|}
\hline Parameters & $\begin{array}{c}\text { Valid } \\
\mathrm{N}\end{array}$ & Mean & $\begin{array}{l}-95 \% \text { confidence } \\
\text { limits of mean }\end{array}$ & $\begin{array}{l}+95 \% \text { confidence } \\
\text { limits of mean }\end{array}$ & Minimum & Maximum & $\begin{array}{l}\text { Standard } \\
\text { Deviation }\end{array}$ & $\begin{array}{c}\text { Standard } \\
\text { error of } \\
\text { mean }\end{array}$ \\
\hline \multicolumn{9}{|c|}{ Urbostratozem } \\
\hline C org, $\%$ & 41 & 2.20 & 1.90 & 2.50 & 0.65 & 4.70 & 0.95 & 0.15 \\
\hline $\mathrm{pH}_{\text {water }}$ & 41 & 7.82 & 7.70 & 7.94 & 6.74 & 8.66 & 0.38 & 0.06 \\
\hline $\mathrm{pH} \mathrm{KCl}$ & 41 & 7.04 & 6.84 & 7.25 & 4.16 & 7.63 & 0.63 & 0.10 \\
\hline $\begin{array}{l}\text { Cation exchange } \\
\text { capacity, meq/100g }\end{array}$ & 41 & 23.71 & 20.88 & 26.55 & 10.20 & 46.00 & 8.98 & 1.40 \\
\hline $\begin{array}{l}\mathrm{CO}_{2} \text { of carbonates, } \\
\%\end{array}$ & 41 & 0.45 & 0.24 & 0.66 & 0.00 & 1.42 & 0.47 & 0.10 \\
\hline \multicolumn{9}{|c|}{ Peat-eutrophied urbostratozem } \\
\hline C org, \% & 22 & 5.81 & 4.81 & 6.80 & 3.10 & 11.30 & 2.24 & 0.48 \\
\hline $\mathrm{pH}_{\text {water }}$ & 22 & 7.48 & 7.33 & 7.63 & 6.97 & 8.07 & 0.33 & 0.07 \\
\hline $\mathrm{pH} \mathrm{KCl}$ & 22 & 6.97 & 6.83 & 7.11 & 6.32 & 7.77 & 0.32 & 0.07 \\
\hline $\begin{array}{l}\text { Cation exchange } \\
\text { capacity, meq } / 100 \mathrm{~g}\end{array}$ & 22 & 38.60 & 34.76 & 42.43 & 15.60 & 50.30 & 8.66 & 1.85 \\
\hline $\begin{array}{l}\mathrm{CO}_{2} \text { of carbonates, } \\
\%\end{array}$ & 22 & 0.50 & 0.29 & 0.70 & 0.00 & 1.42 & 0.47 & 0.10 \\
\hline
\end{tabular}

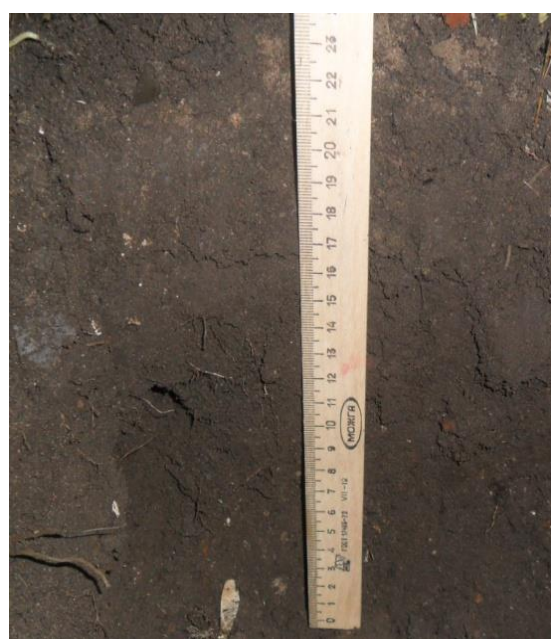

Figure 12. Domesticated (peat-eutrophied) urbostratozem 
Quasi-soils, in which mineral soils are covered with a layer of low-moor peat with a thickness of about $10 \mathrm{~cm}$, are formed on well-maintained plots in relatively new residential areas. In quasi-soils, the "fresh" organogenic layer is characterized by the structure and properties of the peat (Fig. 13).

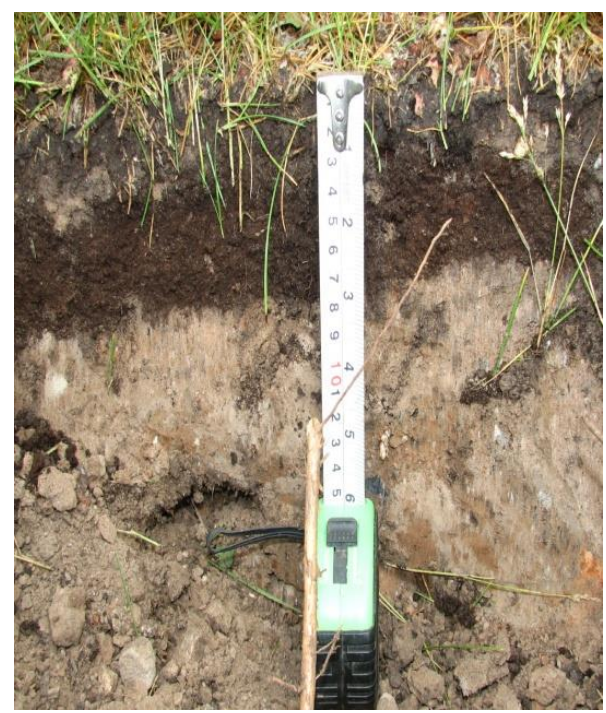

Figure 13. Peat quasi-soil

Over time, this layer is enriched with mineral matter, peat is humified, thus forming a compost-humus quasi-soil (Fig. 14). Quasi-soils, especially peaty ones, contain a lot of organic carbon, they are often characterized by acidity and high cation exchange capacity (Table 2).

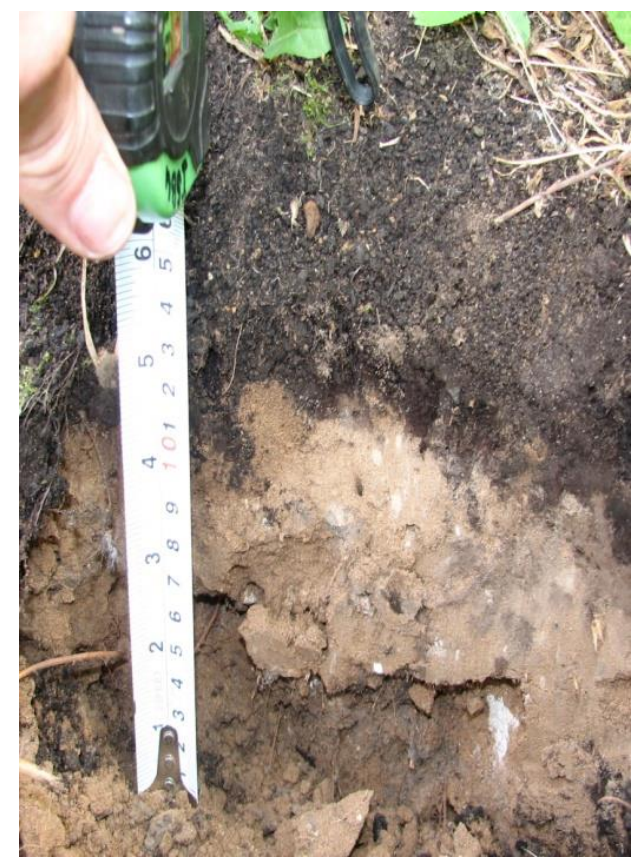

Figure 14. Compost-humus quasi-soil 
Table 2. Properties of the surface layer of quasi-soils $(0-10 \mathrm{~cm})$

\begin{tabular}{l|c|c|c|c}
\hline \multicolumn{1}{c|}{ Parameters } & Valid $\mathrm{N}$ & Mean & Minimum & Maximum \\
\hline \multicolumn{5}{|c|}{ Compost-humus quasi-soil } \\
\hline $\mathrm{C}$ org, \% & 7 & 6.23 & 3.57 & 12.52 \\
\hline $\mathrm{pH}$ water & 7 & 7.30 & 6.28 & 7.83 \\
\hline $\mathrm{pH}$ KCl & 7 & 6.71 & 5.54 & 7.35 \\
$\begin{array}{l}\text { Cation exchange capacity, } \\
\text { meq/100 g }\end{array}$ & 7 & 33.59 & 14.95 & 56.20 \\
\hline $\mathrm{CO}_{2}$ of carbonates, \% & 7 & 1.44 & 0.00 & 3.12 \\
\hline \multicolumn{5}{|c|}{ Peat quasi-soil } \\
\hline $\mathrm{pH}$ org, \% & 7 & 18.90 & 14.44 & 27.30 \\
\hline $\mathrm{pH}$ KCl & 7 & 6.24 & 4.64 & 7.74 \\
\hline $\begin{array}{l}\text { Cation exchange capacity, } \\
\text { meq/100 g }\end{array}$ & 7 & 5.48 & 4.03 & 6.86 \\
\hline
\end{tabular}

The investigated UPCs were represented by Urbostratozems and Quasi-soils, which caused a high heterogeneity of the surface soil layers. Variability of soils properties is demonstrated through the example of UPC-1 on eluvial-deluvial loams (Fig. 15-19).

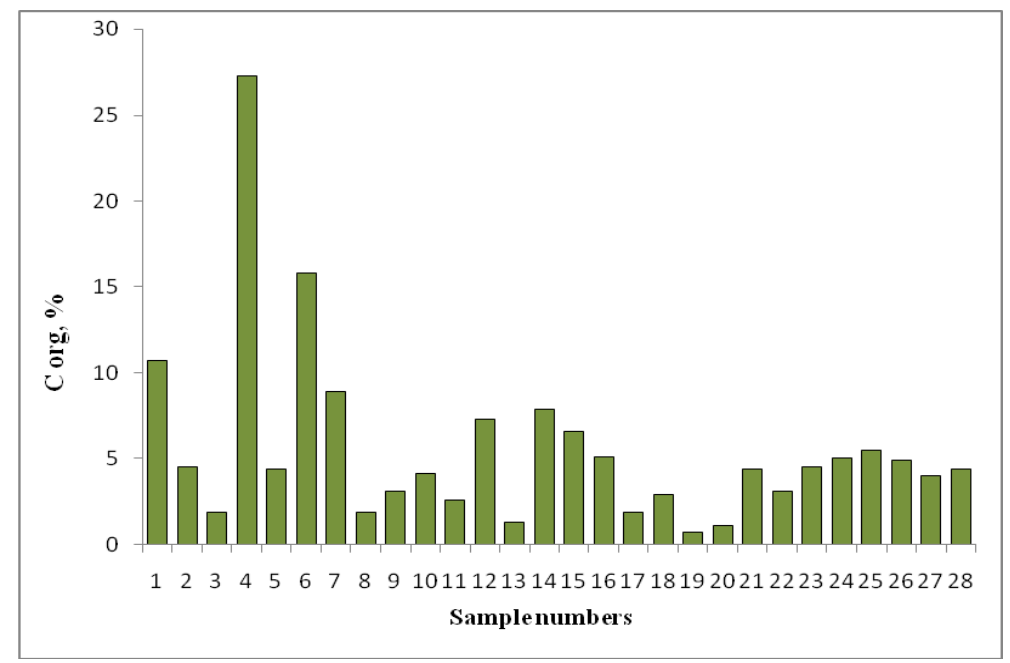

Figure 15. The content of organic carbon in the upper soil layers of the UPC-1

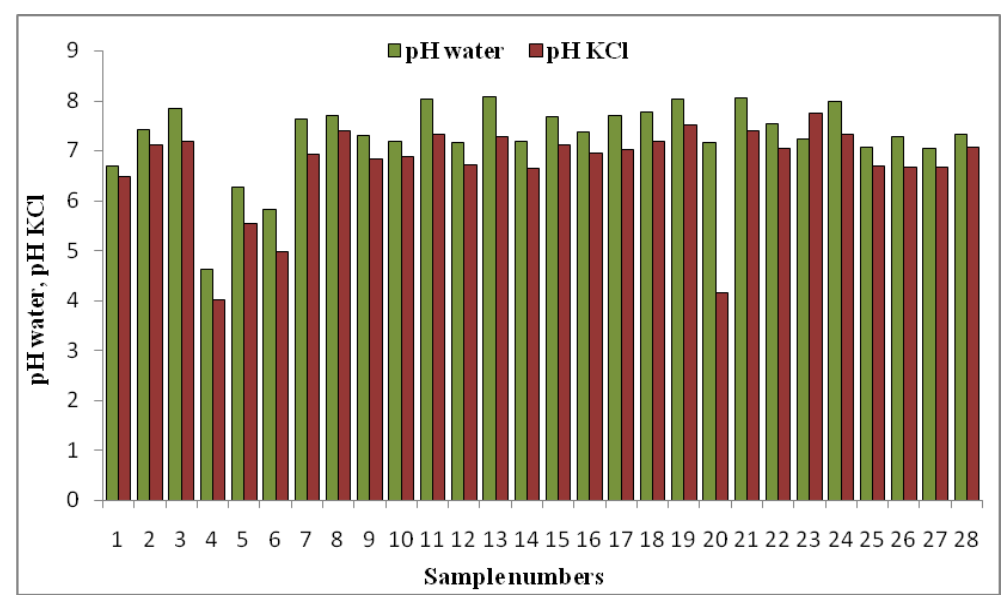

Figure 16. $p H$ value in the upper soil layers of the UPC-1 


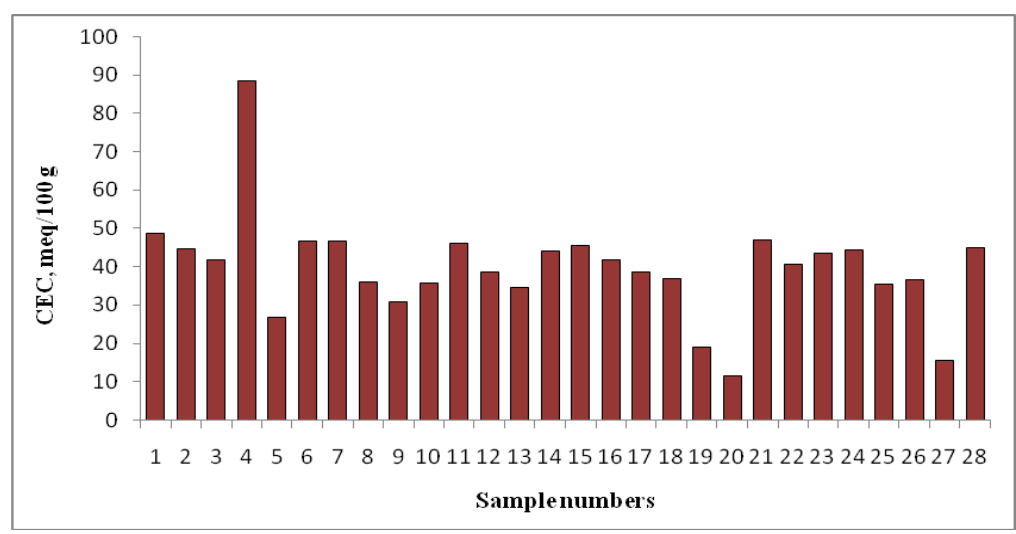

Figure 17. Cation exchange capacity (CEC) in the upper soil layers of the UPC-1

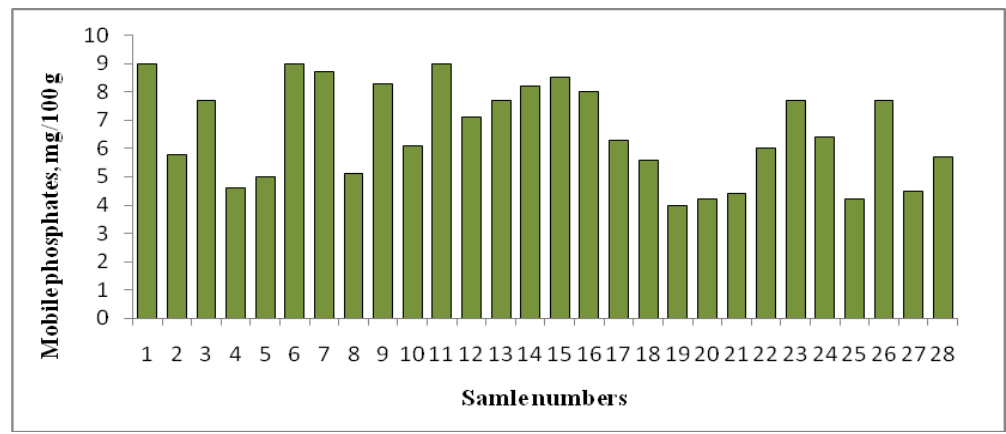

Figure 18. The content of mobile phosphates in the upper soil layers of the UPC-1

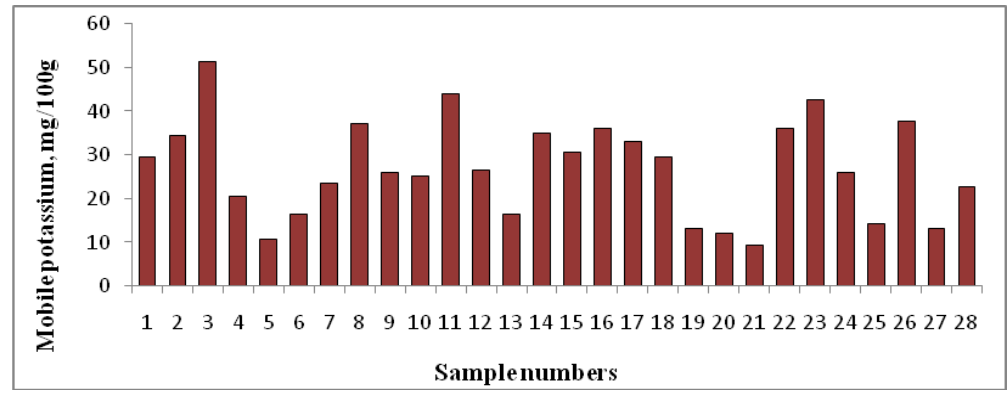

Figure 19. The content of mobile potassium in the upper soil layers of the UPC-1

In the upper layers of urbostratozems and quasi-soils, the mobility of heavy metals (Fig. 20), as a rule, did not exceed the threshold of previously established toxicity for the testing culture, the highest activity was shown by $\mathrm{Cd}$.

At the same time, the state of the surface soil layers was influenced by the lithological differences of the UPC and the age of urban development. On the average, the increased content of organic carbon in the soils of the UPC-1 (Fig. 21) is due to the longer cultivation in this relatively old part of the city. The smallest soil humus content in the relatively young area (UPC-2) is due to weak cultivation, and initially low organic matter content in the sandy soils of the Kama River terraces. In addition, the sandy mineral base of urban soil formation does not contribute to the accumulation of humus. 


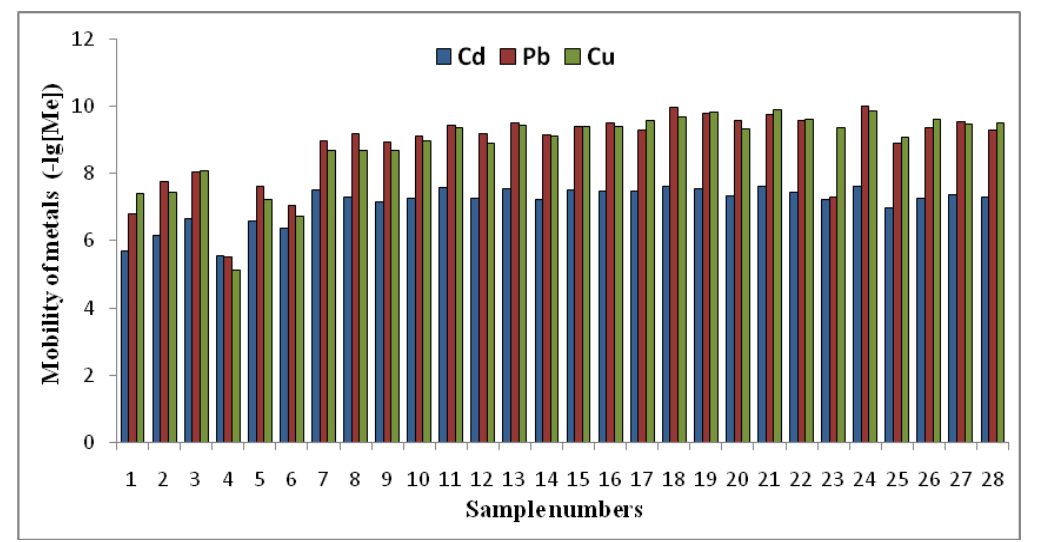

Figure 20. Mobility of metals (-lg [Me]) in the upper soil layers of the UPC-1

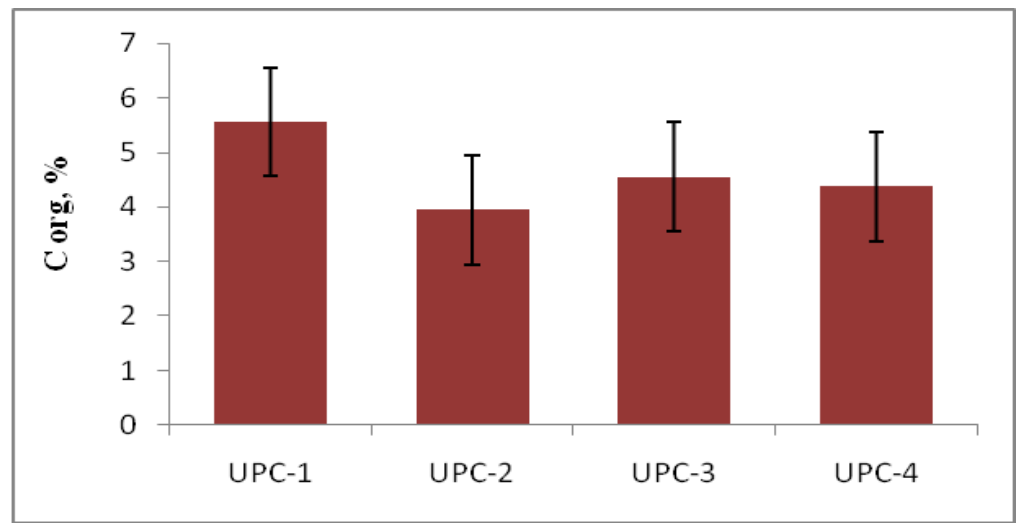

Figure 21. The average content of organic carbon in the upper soil layers of the UPC

The surface soil layers in UPC-1 were, on the average, characterized by lower alkalinity due to the introduction of sour peat (Fig. 22).

Due to the accumulation of organic matter and predominantly heavy loamy granulometric composition, the surface soil layers in UPC-1 were characterized by the highest absorption capacity (Fig. 23). The smallest absorption capacity was in sandy and sandy-loam soils in UPC-2.

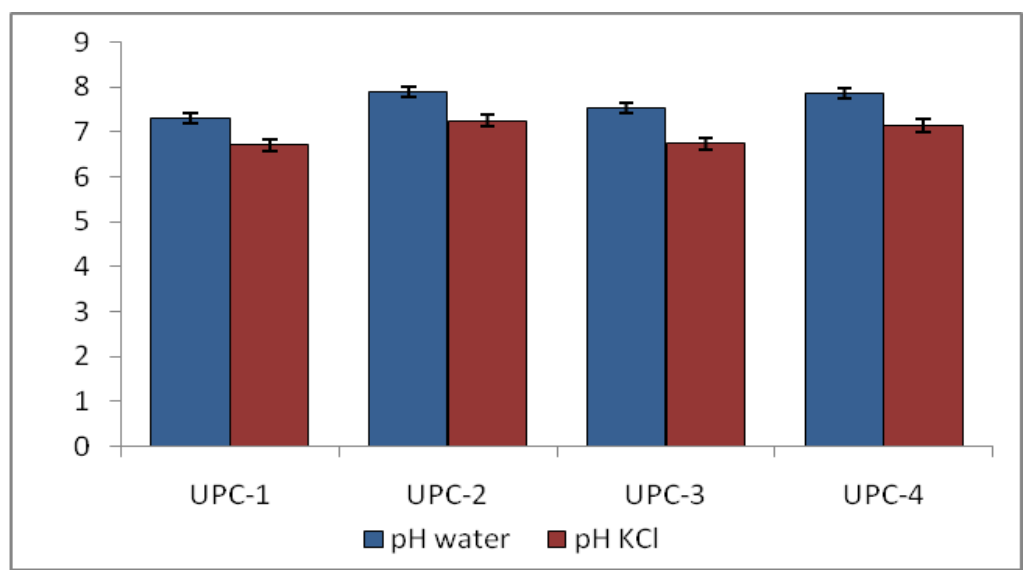

Figure 22. The average $p H$ in the upper soil horizons of the UPC 


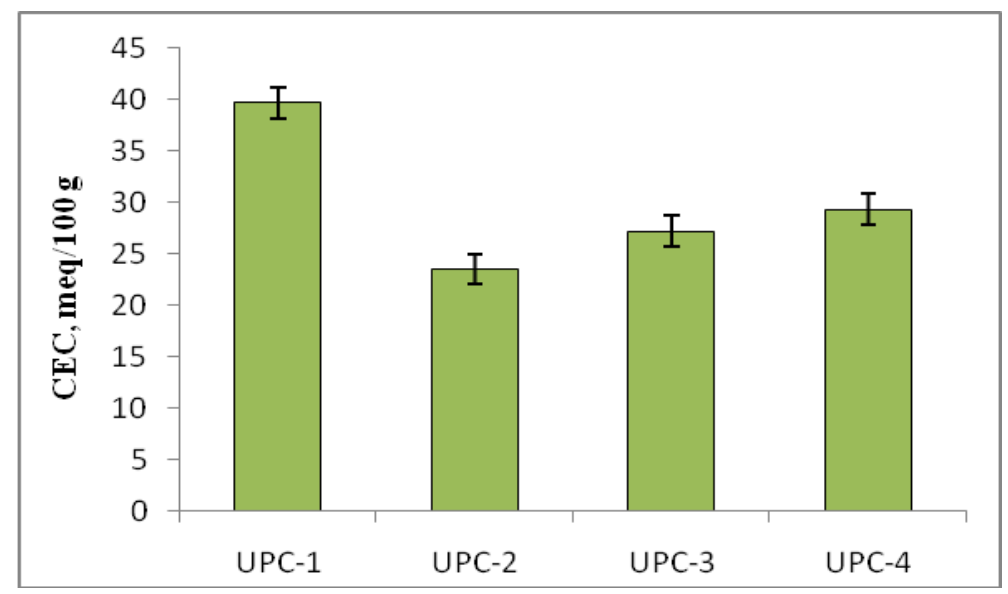

Figure 23. The average cation exchange capacity in the upper soil horizons of the UPC

Soils on ancient alluvial sands (UPC-2) and on alluvial sediments (UPC-4) are less supplied with mobile potassium (Fig. 24), probably because of the lighter granulometric composition of the rocks.

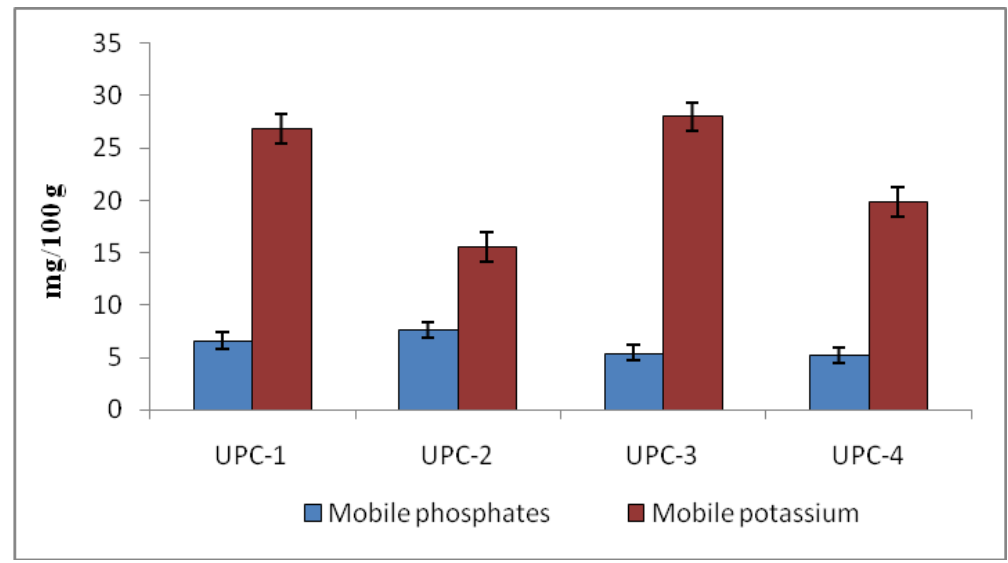

Figure 24. The average content of mobile phosphates and potassium in the upper soil layers of the UPC

\section{Phytotesting of the soils of urban pedocomplexes in residential areas of Perm}

Plants grown on samples from different soils and TSF, differed significantly in morphometric parameters. Watercress on soil samples from UPC-1 had a slight excess in height, or an allowable decrease (less than 30\%) in height and weight relative to the test control, thus the soils had satisfactory ecological condition (Fig. 25). However, in $11 \%$ of soil samples watercress height was reduced by $31-36 \%$ and in $33 \%$ of samples weight was reduced by $31-55 \%$. Thus, about the third part of the samples taken within the given residential areas showed the unsatisfactory condition of the surface layers of urbostratozems and quasi-soils.

Comparison of the height and weight of watercress grown on samples from different UPC showed, on the average, a less favorable ecological condition of the surface soil layers in the UPC-2, probably due to sandy and sandy-loam granulometric composition, poverty of organic matter and low content of mobile potassium (Fig. 26). Relatively 
better condition was found in plants on the soils of the UPC-3; that occurs due to the average granulometric composition, the cultivation of the soil in the household plots, and generally reduced anthropogenic load in the area of low-rise buildings.

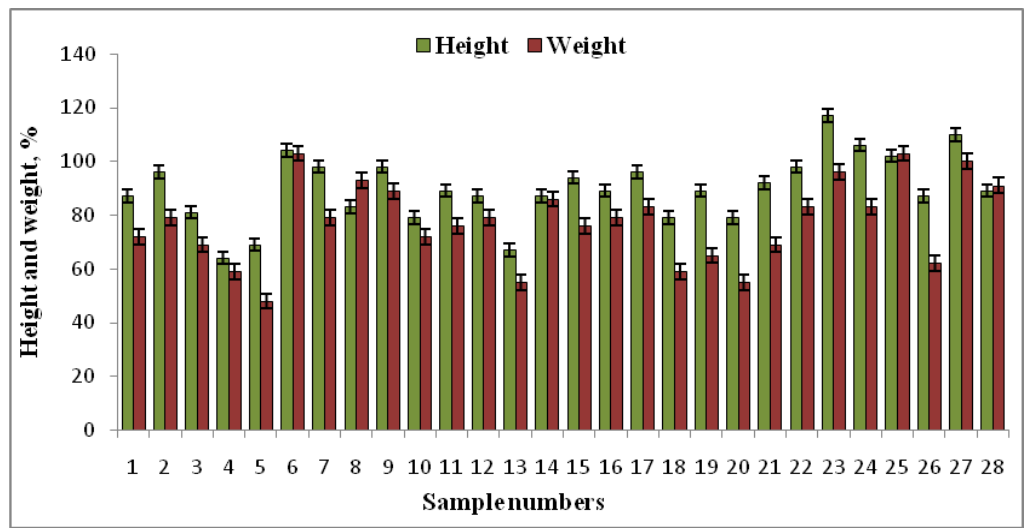

Figure 25. The height and weight of the testing culture, grown on samples from the soil layers of the UPC-1, \% of the test control

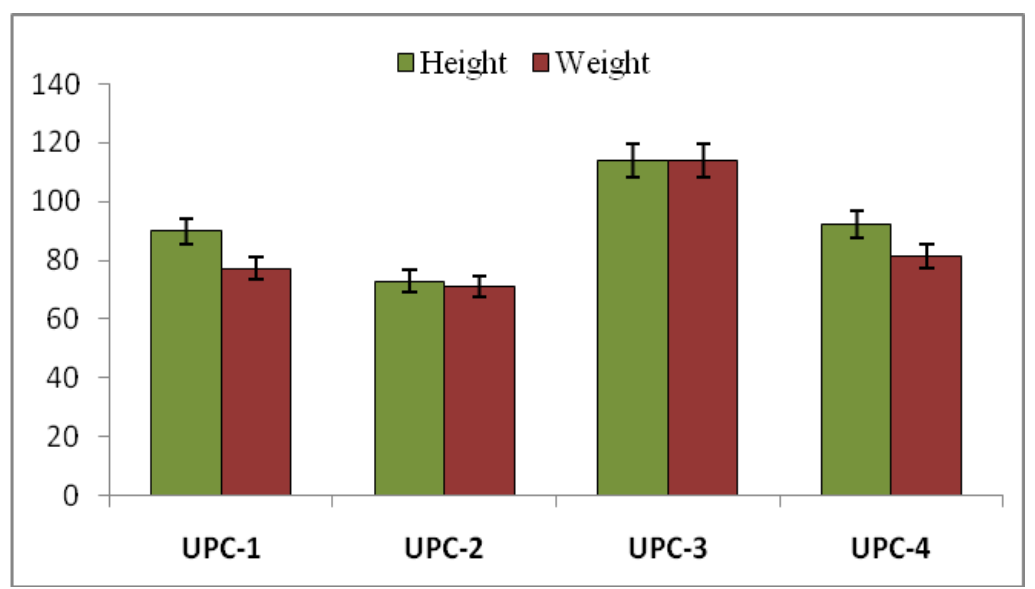

Figure 26. Height and weight of the testing culture (\% of test control) grown on samples from the upper soil layers of the UPC

Using the correlation analysis, there was established the dependence of the watercress status on soil properties (Table 3).

Table 3. Correlation between the state of the testing culture and the properties of the surface layers of urbostratozems and quasi-soils

\begin{tabular}{c|c|c}
\hline Parameters & Height & Weight \\
\hline Organic carbon content & $\mathbf{0 . 3 6} *$ & $\mathbf{0 . 3 7 *}$ \\
Cation exchange capacity & $\mathbf{0 . 4 2} *$ & $\mathbf{0 . 4 1}$ \\
pH water & $\mathbf{- 0 . 4 2 *}$ & $\mathbf{- 0 . 4 6 *}$ \\
pH KCl & $\mathbf{- 0 . 4 4}^{*}$ & $\mathbf{- 0 . 4 7 *}$ \\
Mobile phosphorus & -0.11 & -0.08 \\
Mobile potassium & $\mathbf{0 . 4 4 *}$ & $\mathbf{0 . 4 5 *}$ \\
- $\lg [\mathrm{Pb}]$ & -0.06 & -0.20 \\
$-\lg [\mathrm{Cd}]$ & $\mathbf{- 0 . 3 2}$ & $\mathbf{- 0 . 3 9 *}$ \\
\hline
\end{tabular}

Note. $*$-significant correlation coefficients at $95 \%$ probability level are highlighted in semibold 
The height and weight of plants were positively effected by the content of organic matter, the capacity of cation exchange, the content of mobile potassium in the surface layers of the soil. The test culture showed a negative reaction to the alkalinity of the soil. A positive response of plants to cadmium mobility was revealed (alongside its low activity), which is possibly due to the indirect effect of a decrease in soil alkalinity, in which the availability of the metal is slightly increased.

\section{Discussion}

Despite the general feasibility of using biotesting methods in studying the state of the soil, it is not easy to determine the response of organisms. It is believed that when assessing soil toxicity, it is necessary to involve several organisms from different trophic groups (Keddy et al., 1995; Debus and Hund, 1997; Bierkens et al., 1998; Stephenson et al., 2000; Lisovitskaya and Terekhova, 2010; Rivett et al., 2011; Terekhova, 2011; Pleshakova and Belyakov, 2014; Bardina et al., 2014; Romero-Freire et al., 2015). However, the cultivation of animals, plants, microorganisms requires professional skills. In addition, the reaction of remote groups (producers, decomposers, consumers) to the state of the soil is not straightforward; as a result, the authors often recognize that there is no universal method of biotesting that is suitable for all cases.

In our experiment to assess the ecological state of the soil, we used one type of higher plants - watercress, which showed a response to the genetic properties of the soil, to the mobility of lead and cadmium in them. Certainly, there is a large variety of pollutants in the tested urban soils, which are not determined by the reaction of this testing culture. Thereby, the test control was grown on vermiculite with Knop's solution, the ability of which to create conditions for watercress was compared with the ability of natural soils, including black soil - a standard of regional fertility. The application of the test control allowed to bypass the rule of the only difference that is required to be observed during the phytotesting of the test (polluted) and control soil (Eisentraeger et al., 2004; Lisovitskaya and Terekhova, 2010).

Natural-anthropogenic soil formation in residential areas of the city of Perm has led to the formation of a very heterogeneous soil cover, the properties of the surface soil layers vary in a wide range. Urbostratozems with the urbic horizon prevailed in the soil cover of residential areas, in relatively old areas they were formed alongside certain reclamation - by repeatedly dumping peat from the lowlands. There is a general tendency towards accumulation of carbonates in urban soils (Yang and Zhang, 2015), but on the territory of Perm the enrichment of the soil with dispersed carbonates is due to the widespread use of carbonate rubble and gravel. Due to the presence of carbonate salts, the soils have a neutral alkaline $\mathrm{pH}$, which is affected for a relatively short period by the introduction of acidic peat.

The bioavailability of metals depends on the acid-base, redox properties, the quality and quantity of organic substances, the strength of the absorbing complex and other parameters; it decreases with the increase of $\mathrm{pH}$ and in the presence of other metals and chelators in the soil. The total accumulation of heavy metals does not always mean the increase of the soil toxicity, since the soil has a certain buffer capacity (Duchovskis et al., 2003; Romero-Freire et al., 2015). Despite the general accumulation of heavy metals in the non-acidic soils of our city (Eremchenko and Moskvina, 2005), their mobility was low. The negative effect of $\mathrm{Cd}, \mathrm{Pb}$ mobility on the height and weight of the test culture has not been established. 
The concept of "urban complexes" is used in the soil cover mapping of some large cities (New York City Soil Survey Staff, 2005; Sobocka, 2010). Our research has shown that a similar approach is very promising in assessing the ecological state of the surface soil layers. The soils of the UPC in Perm inherited some of the properties of the original soil-forming rocks and soils, primarily related to the particle size distribution, which regulates the water retention and absorption capacity, the availability of chemical elements, the rate of mineralization of organic matter, etc.

Despite the high variation of the soil and TSF properties in urban pedocomplexes, the use of phytotesting shows a generally satisfactory condition of the upper soil layers of residential areas. Soil biotesting in St. Petersburg also showed a satisfactory ecological condition of urban soils, in summer they had no toxicity (Bardina et al., 2013). However, in a relatively old area of the city of Perm, there were revealed the areas where the state of the soil was unsatisfactory. The tendency towards deterioration of the soil ecological condition will develop with modern ways land use and the accumulation of pollutants. According to the results of phytotesting, the most favorable condition was in the soil of a residential area with the distribution of low-rise buildings located near the park area.

\section{Conclusions}

This study validates the response of watercress to the leading parameters of soil fertility and the level of soil toxicity. This plant as a testing culture showed mainly a satisfactory condition of the upper layers of soil cover in residential areas of the city of Perm. At the same time, in the areas of relatively old development, a trend towards the emergence of soil toxicity was revealed. In the environmental assessment of soils and the subsequent monitoring of their condition, the idea of urban pedocomplexes occurred to be promising, since the included soils inherit lithological features, on which the specificity of urban soil formation depends. The usage of vermiculite with Knop solution as a test control can be used in the study of various man-made soils and grounds, and we recommend the preliminary comparison of the plants' condition (height and weight) on vermiculite with plants grown on fertile regional soils.

\section{REFERENCES}

[1] Bardina, T. V., Chugunova, M. V., Bardina, V. I. (2013): Study of the urban soils ecotoxicity using biotesting methods. - Zhivyye i biokosnyye sistemy, 5. Available at: http://www.jbks.ru/archive/issue-5/article-8.pdf (accessed 13.02.2018) (In Russian).

[2] Bardina, T. V., Chugunova, M. V., Kulibaba, V. V., Bardina, V. I. (2014): Evaluation of the ecological state of the past environmental damage objects soils with bio-testing methods. - Regional Environmental Issues 5: 37-41. (In Russian).

[3] Bierkens, J., Klein, G., Corbisier, P., Van Den Heuvel, R., Schoeters, G. (1998): Comparative sensitivity of 20 bioassays for soil quality. - Chemosphere 37: 2935-2947.

[4] Byrne, L. B., Bruns, M. A. (2008): Ecosystem properties of urban land covers at the aboveground-belowground interface. - Ecosystems 11: 1065-1077. DOI: 10.1007/s10021-008-9179-3.

[5] Czerniawska-Kusza, I., Ciesielczuk, T., Kusza, G., Cichon, A. (2006): Comparison of the Phytotoxkit microbiotest and chemical variables for toxicity evaluation of sediments. - Environmental Toxicology 21(4): 367-372. 
[6] Debus, R., Hund, K. (1997): Development of analytical methods for the assessment of ecotoxicological relevant soil contamination. - Chemosphere 35: 239-261.

[7] Dobrovolskiy, G. V. (1997): Pochva, Gorod, Ekologiya [Soil, city, environment]. - Fond "Za Ekonomicheskuyu Gramotnost", Moscow, Russia (In Russian).

[8] Duchovskis, P., Yuknis, R., Brazaitite, A., Zukauskaite, I. (2003): Plant response to integrated impact of natural and anthropogenic stress factors. - Russian Journal of Plant Physiology 50(2): 147-154.

[9] Eisentraeger, A., Rila, J.-P., Hund-Rinke, K., Roembke, J. (2004): Proposal of a testing strategy and assessment criteria for the ecotoxicological assessment of soil and soil materials. - Journal of soils and sediments 4(2): 123-128.

[10] Eremchenko, O. Z., Moskvina, N. V. (2005): Properties of soils and technogenic surface formations in the areas of multi-storey districts in Perm City. - Eurasian Soil Science 7: 688-694.

[11] Eremchenko, O. Z., Shestakov, I. E., Moskvina, N. V. (2016): Pochvy i tekhnogennyye poverkhnostnyye obrazovaniya urbanizirovannykh territoriy Permskogo Prikam'ya (Soils and technogenic surface formations of urbanized territories of the Perm Prikamye). PSU, Perm, Russia (In Russian).

[12] Eremchenko, O. Z., Mitrakova, N. V. (2017): Sposob ocenki biologicheskoy aktivnosti I toksichnosti pochv i technogennyh pochvogruntov [A method for assessing the biological activity and toxicity of soils and man-caused soil grounds]. - Patent of the Russian Federation. N 2620555 (In Russian).

[13] Evolution of soils and soil cover. Theory, diversity of natural evolution and anthropogenic transformations of soils (2015). - In: Ivanov, I. V., Kudeyarov, V. N. (eds.) GEOS, Moscow, Russia.

[14] Gareeva, E. V. (2018): Application of the method of phytotesting for assessing the ecological safety of the environment within the exploited fields of Gazprom Dobycha Nadym. - Gas industry 2(764): 66-72. (In Russian).

[15] Gong, P., Wilke, B.-M., Strozzi, E., Fleischmann, S. (2001): Evaluation and refinement of a continuous seed germination and early seedling growth test for the use in the ecotoxicological assessment of soils. - Chemosphere 44: 491-500.

[16] Juvonen, R., Martikainen, E., Schultz, E., Joutti, A., Ahtiainen, J. (2000): A battery of toxicity tests as indicators of decontamination in composting oily wastes. Ecotoxicology and Environmental Safety 47: 156-166.

[17] Kabata-Pendias, A. (2011): Trace elements in soils and plants. - 4th ed. CRC Press, Taylor and Francis Group, Boca Raton, USA.

[18] Keddy, C. J., Greene, J. C., Bonell, M. A. (1995): Review of whole - organism bioassays: soil, freshwater sediment, and freshwater assessment in Canada. Ecotoxicology and Environmental Safety 30: 221-251.

[19] Kolesnikov, S. I., Aznaurian, D. K., Kazeev, K. S., Val'kov, V. F. (2010): Biological properties of south Russian soils: Tolerance to oil pollution. - Russian Journal of Ecology 41(5): 398-404. (In Russian).

[20] Lisovitskaya, O. V., Terekhova, V. A. (2010): Phytotesting: basic approaches, problems of the laboratory method and modern solutions. - Reports on environmental soil science 1(13): 1-18. (In Russian).

[21] Marcotullio, P. J. (2011): Urban soils. - In: Douglas, J., Goode, D., Houck, M., Wang, R. (eds.) The Routledge handbook of urban ecology. Routledge, New York.

[22] Maxam, G., Rila, J.-P., Dott, W., Eisentraeger, A. (2000): Use bioassays for assessment of water-extractable ecotoxic potential of soil. - Ecotoxicology and Environmental Safety 45: 240-246.

[23] Mayachkina, N. V., Chugunova, M. V. (2009): Features of soil biotesting with the aim of their ecotoxicological assessment. - Vestnik of Lobachevsky University of Nizhni Novgorod 1: 84-93. (In Russian). 
[24] Nechaev, M. G. (2000): Perm' ot osnovaniya do nashikh dney: istoricheskiye ocherki [Perm from the foundation to the present day: historical essays]. - Knizhnyy mir, Perm, Russia (In Russian).

[25] New York City Soil Survey Staff (2005): New York City reconnaissance soil survey. Staten Island, New York, USA.

[26] Nikolaeva, O. V., Terekhova, V. A. (2017): Improvement of laboratory phytotest for the ecological evaluation of soils. - Eurasian Soil Science 50: 1105-1114.

[27] Pickett, S. T. A., Cadenasso, M. L. (2009): Altered resources, disturbance, and heterogeneity: A framework for comparing urban and non-urban soils. - Urban Ecosystems 12: 23-44. DOI 10.1007/s11252-008-0047-x.

[28] Pleshakova, E. V., Belyakov, A. Y. (2014): Using various methods of biotesting to assess the toxic effect on the soil of invert-emulsion drilling fluids and their dispersion phase. Moscow University Soil Science Bulletin 1: 38-43. (In Russian).

[29] Pouyat, R. V., Russell-Anelli, J., Neerchal, N. K. (2007): Soil chemical and physical properties that differentiate urban land-use and cover types. - Soil Science Society of America Journal 71: 1010-1019. DOI:10.2136/sssaj2006.0164.

[30] Prokof'eva, T. V., Gerasimova, M. I., Bezuglova, O. S., Gorbov, S. N., Bakhmatova, K. A., Matinyan, N. N., Gol'eva, A. A., Zharikova, E. A., Nakvasina, E. N., Sivtseva, N. E. (2014): Inclusion of soils and soil-like bodies of urban territories into the Russian soil classification system. - Eurasian Soil Science 47(10): 959-967.

[31] Rivett, M. O., Sadler, J. P., Barnes, B. C. (2011): Urban contaminated land. - In: Douglas, J., Goode, D., Houck, M., Wang, R. (eds.) The Routledge handbook of urban ecology. Routledge, New York.

[32] Romero-Freire, A., Martin Peinado, F. J., Van Gestel, C. A. M. (2015): Influence of soil properties on the toxicity of metal-polluted soils: comparison of different bioassay methods. - Journal of hazardous materials 289: 46-53.

[33] Shestakov, I. E., Eremchenko, O. Z., Fil'kin, T. G. (2013): Approaches toward soil mapping of urban territories with the city of Perm as an example. - Eurasian Soil Science 46(12): 1130-1138.

[34] Shunelko, E. V., Fedorova, A. I. (2000): Environmental assessment of urban soils and identification of the level of toxicity of heavy metals by biotesting method. - Proceedings of Voronezh State University. Series: Geography. Geoecology 4: 77-83. (In Russian).

[35] Sizov, A. P. (2008): Estimation of the value potential of soils and lands in the city of Moscow. - Kadastrovyy vestnik 1: 72-75. (In Russian).

[36] Sobocká, J. (2010): Specifics of urban soils (Technosols) survey and mapping. - 19th World Congress of Soil Science, Soil Solutions for a Changing World 1-6 August 2010, Brisbane, Australia.

[37] Stephenson, G. L., Koper, N., Atkonson, G. F., Solomon, K. R., Scroggins, R. P. (2000): Use of nonlinear regression techniques for describing concentration-response relationships of plant species exposed to contaminated site soils. - Environmental Toxicology and Chemistry 19: 2968-2981.

[38] Sujetovienè, G., Griauslyte, L. (2008): Toxicity assessment of roadside soil using wild oat (Avena sativa L.) and cress (Lepidium sativum L.) morphometric and biochemical parameters. - Environmental Research, Engineering and Management 46(4): 29-35.

[39] Terekhova, V. A. (2011): Soil bioassay: Problems and approaches. - Eurasian Soil Science 44(2): 173-179.

[40] Timofeev, M. A., Terekhova, V. A., Kozhevin, P. A. (2010): Biotesting for cadmium pollution in soils. - Moscow University Soil Science Bulletin 65(4): 179-182.

[41] Van der Vliet, L., Velicogna, J., Princz, J., Scroggins, R. (2012): Phytotoxkit: A critical look at a rapid assessment tool. - Environmental Toxicology and Chemistry 31(2): 316323. 
[42] Vasilyev, A. A., Chashchin, A. N. (2011): Heavy metals in the soils of the city of Chusovoy: assessment and diagnostics of pollution. - FSBEI HE Perm SATU, Perm, Russia (In Russian).

[43] Voronchikhina, E. A., Zaporov, A. Y. (1998): Ecological aspects of environmental pollution with heavy metals. - Voprosy fizicheskoy geografii i geoekologii Urala: 139147. (In Russian).

[44] Voronina, L. P. (2009): Ecological functions of the complex of agrochemical agents and plant growth regulators in agrocenosis. - Abstract of D. Sci. dissertation, Moscow State University, Moscow, Russia (In Russian).

[45] World Reference Base for Soil Resources (2006): World Soil Resources Reports, 103. FAO, Rome.

[46] Yang, J.-L., Zhang, G.-L. (2015): Formation, characteristics and eco-environmental implications of urban soils - A review. - Soil Science and Plant Nutrition 61: 30-46. 